\title{
Effects of aeolian processes on nutrient loss from surface soils and their significance for sandy desertification in Mu Us Desert, China: a wind tunnel approach
}

\author{
LANG Lili $^{1}$, WANG Xunming ${ }^{1,2^{*}}$, WANG Guangtao ${ }^{2}$, HUA Ting ${ }^{2}$, WANG Hongtao ${ }^{2}$ \\ ${ }^{1}$ Key Laboratory of Water Cycle \& Related Land Surface Processes, Institute of Geographic Sciences and Natural Resources \\ Research, Chinese Academy of Sciences, Beijing 100101, China; \\ ${ }^{2}$ Key Laboratory of Desert and Desertification, Cold and Arid Regions Environmental and Engineering Research Institute, \\ Chinese Academy of Sciences, Lanzhou 730000, China
}

\begin{abstract}
Mu Us Desert, a region with high aeolian activity, is at extremely high risk of sandy desertification. Using surface soil samples collected from Mu Us Desert of northern China, we evaluated the effects of aeolian processes on nutrient loss from surface soils by employing wind tunnel experiments. The experiments were conducted using free-stream wind velocities of $14,16,18$ and $22 \mathrm{~m} / \mathrm{s}$. Our results showed that the fine particles $(<50 \mu \mathrm{m}$ in diameter; $12.28 \%$ of all transported materials) carrying large nutrient loadings were exported outside the study area by aeolian processes. After the erodible fine particles were transported away from the soil surfaces at low wind velocity (i.e. $14 \mathrm{~m} / \mathrm{s}$ ), the following relatively high wind velocity (i.e. $22 \mathrm{~m} / \mathrm{s}$ ) did not have any significant effect on nutrient export, because the coefficients of variation for soil organic matter, total phosphorus, total nitrogen and available potassium were usually $<5 \%$. Our experimental results confirmed that aeolian processes result in a large amount of nutrient export, and consequently increase the risk of sandy desertification in arid and semi-arid ecosystems.
\end{abstract}

Keywords: sandy desertification; aeolian activity; soil nutrients; Mu Us Desert

\begin{abstract}
Citation: LANG Lili, WANG Xunming, WANG Guangtao, HUA Ting, WANG Hongtao. 2015. Effects of aeolian processes on nutrient loss from surface soils and their significance for sandy desertification in Mu Us Desert, China: a wind tunnel approach. Journal of Arid Land, 7(4): 421-428. doi: 10.1007/s40333-015-0043-y
\end{abstract}

In China, 'aeolian desertification' or 'sandy desertification' (Wang, 2013a), a type of vegetation loss that is characterized by the appearance of degraded land, mainly occurs at the margins of mobile sandy deserts, sandy lands, cultivated grasslands, steppes and gobi deserts (Huang et al., 2001; Li et al., 2005; Wang et al., 2005a, 2007, 2008a; Hoffmann et al., 2011). In these areas, aeolian processes erode surface sediments (Shao, 2008) and result in spatial heterogeneity of surface soils (Okin and Gillette, 2001), and are also the key abiotic mechanism for soil nutrient export (Schlesinger et al., 1990; Schlesinger and Pilmanis, 1998; Okin et al., 2009). Along with aeolian processes, the risk of sandy desertification also increases in mobile sandy deserts and sandy lands of various arid, semi-arid and some semi-humid regions (Zhang et al., 2003; Wang et al., 2008b; Shao et al., 2011). During aeolian processes, the coarse particles $(>50 \mu \mathrm{m}$ in diameter) travel short distances and may increase the heterogeneity of soil resources at landscape scale, producing 'islands of fertility' (Garner and Steinberger, 1989; Field et al., 2012); however, large quantities of fine particles $(<50 \mu \mathrm{m}$ in diameter) with abundant nutrients are exported (Zobeck et al., 1989; Leys and McTainsh, 1994). Over recent decades, simulations and field experiments have indicated a close relationship

\footnotetext{
*Corresponding author: WANG Xunming (E-mail: xunming@1zb.ac.cn) Received 2014-10-08; revised 2014-12-26; accepted 2015-01-05

(C) Xinjiang Institute of Ecology and Geography, Chinese Academy of Sciences, Science Press and Springer-Verlag Berlin Heidelberg 2015
} 
between the spatial heterogeneity of soil resources and aeolian processes (Schlesinger and Pilmanis, 1998; Ravi et al., 2009). Although the ecological effects of aeolian inputs on steppe and fynbos ecosystems in Africa have been evaluated (Reynolds et al., 2001; Soderberg and Compton, 2007; Okin et al., 2008), the loss of nutrients from surface soils in arid and semi-arid regions of China remains poorly understood.

In arid and semi-arid regions of China, sandy desertification is closely associated with aeolian processes (Wang et al., 2005a, 2007). At the landscape scale, there has been a decrease in the area of steppe vegetation, which included high-grade forage has been replaced by low-grade grassland vegetation and anchored dunes have become semi-anchored or mobile dunes (Wang et al., 2006). Although nutrient loss resulting from surface sediment export is the key mechanism of land degradation during the sandy desertification process (Schlesinger et al., 1990; Dong et al., 1995; Li et al., 2010; Field et al., 2012), its quantification and contribution to sandy desertification in arid, semi-arid and some semi-humid regions of China remains poorly understood. In addition, studies on nutrient loss associated with land degradation have been widely conducted at the landscape scale using field observations (e.g. Larney et al., 1998; Hobbs and Harris, 2001; Li et al., 2007, 2008; Okin et al., 2009), but few studies have attempted to employ a wind tunnel to investigate soil nutrient loss under different soil and wind regimes. Therefore, in this study we employed wind tunnel experiments to analyze nutrient loss from collected soil samples in the Mu Us Desert and the redistribution of nutrients under various stresses caused by aeolian processes.

\section{Study area}

The study area $\left(37^{\circ} 49^{\prime}-38^{\circ} 05^{\prime} \mathrm{N}, 106^{\circ} 59^{\prime}-107^{\circ} 35^{\prime} \mathrm{E}\right.$; 1,320-1,470 m asl; Fig. 1) is located in the Mu Us Desert, which has been identified as a region with high aeolian activity and is at extremely high risk of sandy desertification (Middleton and Thomas, 1992; Wang et al., 2005b). Details of the regional environment have been described by Wang et al. (2013b). The

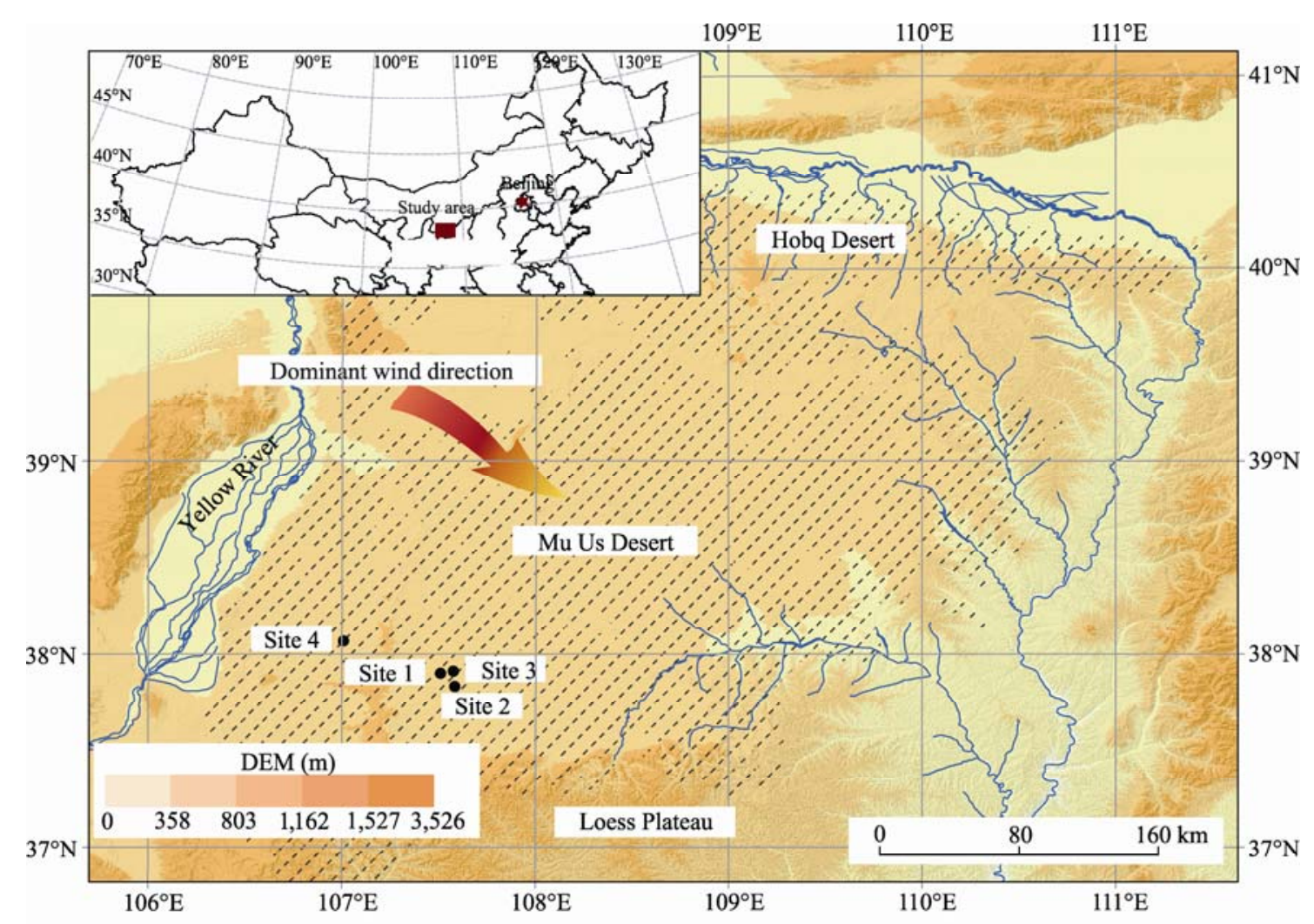

Fig. 1 Location of the Mu Us Desert and the sampling sites in this study 
study area has a semi-arid climate with a mean annual precipitation of $294 \mathrm{~mm}$, an actual annual evaporation of 2,060 mm (1954-2002) and an annual mean wind velocity of $2.7 \mathrm{~m} / \mathrm{s}$. The average frequency of dust storms is 123 days per year with standard visibility of $<10 \mathrm{~km}$. The landscape is a desert steppe with some anchored, semi-anchored and mobile dunes. Dominant plant species, which are mostly annual herbaceous plants, include Salix psammophila, Caragana microphylla, Stipa grandis, Stipa bungeana, Agropyron cristatum, Thymus serpyllum var. mongolicus, Caragana tibetica, Oxytropis aciphylla, Nitraria sibirica and Kalidium foliatum.

\section{Methods}

\subsection{Field sampling}

In November 2012, we collected 20 undisturbed soil samples from the steppe surface of four sampling sites (five samples per site; Fig. 1) using $30 \mathrm{~cm} \times 30 \mathrm{~cm} \times 30$ $\mathrm{cm}$ sample boxes. Details of the sampling process have been described by Wang et al. (2012a). In summary, the criteria for the samples collected at each site were that they were intact (sealed with no cracks) and free from anthropogenic impacts. The surface and underlying sediments of all the samples were anchored aeolian sands. The vegetation cover in the study sites was more than $90 \%$. To extract an undisturbed sample, we placed a sample box on the surface and carefully removed the soil from around the box to a depth of approximately $60 \mathrm{~cm}$, taking care to avoid disturbing the sides of the sample, until the box could be pressed downwards to enclose the surface material. A rigid wooden sheet was then inserted horizontally to form the base of the box, enabling the sample to be withdrawn intact. The box was covered to protect the sample surface, and steel wires were used to wrap the box and to ensure that its contents were not disturbed during the process of transport.

\subsection{Wind tunnel experiments}

Wind tunnel experiments were conducted at the Key Laboratory of Desert and Desertification, Cold and Arid Regions Environmental and Engineering Research Institute, Chinese Academy of Sciences, Lanzhou of China. The blow-type and non-circulating wind tunnel had a total length of $37.8 \mathrm{~m}$ with a 16.2-m-long test section. The cross-sectional area of the test section was $0.6 \mathrm{~m} \times 1.0 \mathrm{~m}$. The free-stream wind velocity in the wind tunnel could be adjusted from 1 to $40 \mathrm{~m} / \mathrm{s}$, as described in detail by Dong et al. (2004) and Wang et al. (2012a, 2013b). We fixed each sample in place in the working section of the wind tunnel with the sample surface at the same level as the bottom of the tunnel. To collect the windblown materials, we installed a sand trap of $30-\mathrm{cm}$ width (the same width as the surface sample) and $30-\mathrm{cm}$ height (Fig. 2), which can collect more than $95 \%$ of the transported materials (Wang et al., 2012b) at a distance of $10 \mathrm{~cm}$ downwind from the sample.

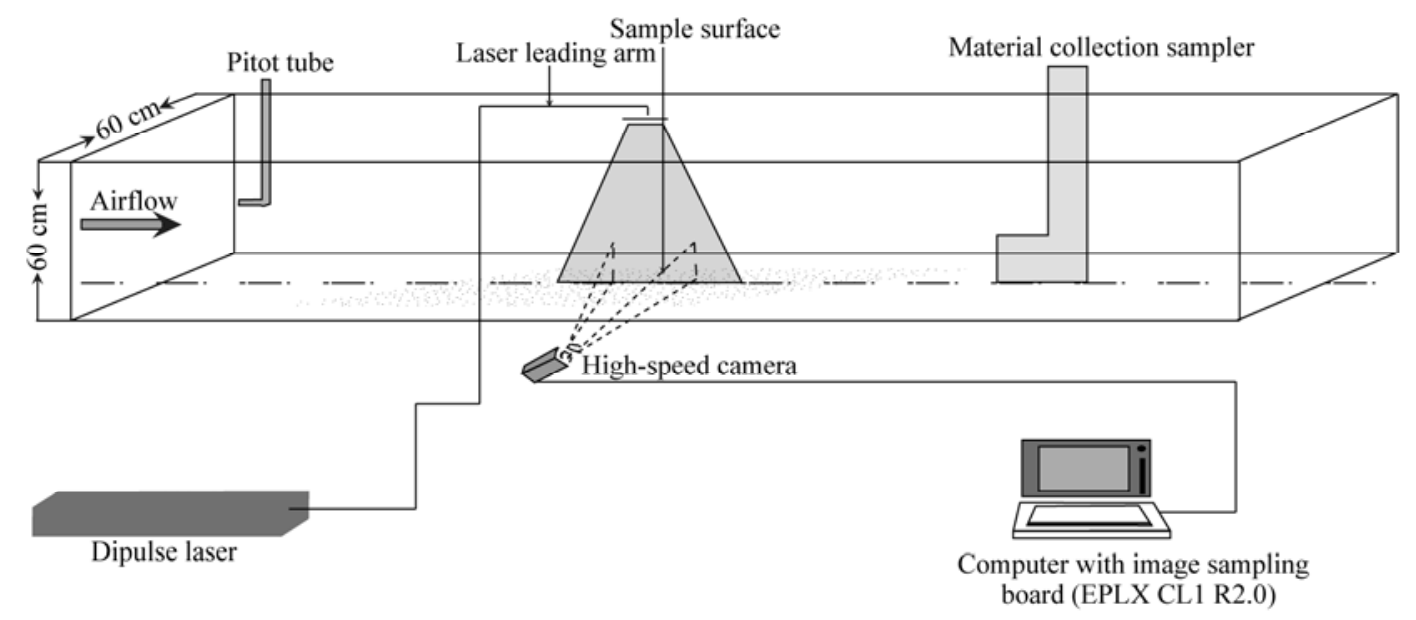

Fig. 2 The wind tunnel and arrangement of samples used in the wind tunnel experiments (modified after Wang et al. (2012a, b) and Wang (2013a)) 
During the wind tunnel experiments, the relative humidity of the atmosphere was $35 \%-42 \%$, which was similar to the humidity during the period when the soil samples were collected. We used clean wind (without saltating clouds) to assess the direct aeolian transport. We conducted the experiments using free-stream wind velocities of 14, 16, 18 and $22 \mathrm{~m} / \mathrm{s}$ which were determined by a Pitot tube (Fig. 2). The experimental duration for each wind velocity was $360 \mathrm{~s}$. Following the cessation of aeolian transport for each wind velocity, we emptied the sediment sampler and weighed the total amount of sediment collected. In addition, each sample was tested under three sets of conditions designed to simulate different levels of human impact (no impact, moderate impact and severe impact) at the various experimental wind velocities. For moderate and severe impact, samples were first half-crushed and completely crushed to simulate states of moderate and severe human impact, respectively.

\subsection{Sample treatment and analysis}

Following completion of the wind tunnel experiments, the collected aeolian materials were weighed (balance precision $0.001 \mathrm{~g}$ ) and subjected to particle size analysis (Mastersizer 2000; Malvern Co. Ltd., Malvern, UK). The sample diameters ranged from 0.02 to $2,000 \mu \mathrm{m}$. Nutrient analyses included measurements of soil organic matter (SOM), total nitrogen (total $\mathrm{N}$ ), total phosphorus (total $\mathrm{P}$ ), total potassium (total $\mathrm{K}$ ), available $\mathrm{N}$ ( $\left.\mathrm{N}_{\text {avail }}\right)$, available $\mathrm{P}\left(\mathrm{P}_{\text {avail }}\right)$ and available $\mathrm{K}\left(\mathrm{K}_{\text {avail }}\right)$. SOM was determined from the soil organic carbon content, which was measured by dichromate oxidation using the Walkley Black procedure (Nelson and Sommers, 1982). Total $\mathrm{N}$ was measured using the micro-Kjeldahl procedure; total $\mathrm{P}$ was measured colorimetrically using a spectrophotometer following $\mathrm{H}_{2} \mathrm{SO}_{4}-\mathrm{HClO}_{4}$ digestion; and total $\mathrm{K}$ was measured using flame photometry following $\mathrm{HF}-\mathrm{HClO}_{4}$ digestion. $\mathrm{N}_{\text {avail }}$ was determined using the alkaline diffusion method; $\mathrm{P}_{\text {avail }}$ was measured using the Olsen method; and $\mathrm{K}_{\text {avail }}$ was assessed using the colorimetric method with $\mathrm{NH}_{4} \mathrm{OAc}$ extraction. As a consequence of the limited quantities of collected aeolian material available, only the surface soil of samples was used for detailed nutrient analyses. Therefore, we used correlation analysis for discussing the nutrient content of the transported materials (see Bosatta and Ågren, 1997; Dexter, 2004).

\section{Results and discussion}

\subsection{Nutrient content of surface soils}

The mean nutrient contents of the surface soils in this region were $8.80 \mathrm{~g} / \mathrm{kg}$ for $\mathrm{SOM}, 0.60 \mathrm{~g} / \mathrm{kg}$ for total $\mathrm{N}$, $0.82 \mathrm{~g} / \mathrm{kg}$ for total $\mathrm{P}, 11.00 \mathrm{~g} / \mathrm{kg}$ for total $\mathrm{K}, 39.98$ $\mathrm{mg} / \mathrm{kg}$ for $\mathrm{N}_{\text {avail }}, 15.95 \mathrm{mg} / \mathrm{kg}$ for $\mathrm{P}_{\text {avail }}$ and 209.50 $\mathrm{mg} / \mathrm{kg}$ for $\mathrm{K}_{\text {avail }}$ (Table 1). We found the differences in the nutrient contents among different sites with the coefficients of variation (CVs) among the surface sediments ranging from $19 \%$ to $37 \%$ except for total $\mathrm{K}$, which showed almost no variation in nutrient concentrations among the surface sediment samples.

\subsection{Particle size composition and its relationship with the nutrient content}

The silt and clay fractions $\left(<50 \mu \mathrm{m}\right.$ in diameter; $\left.\mathrm{PM}_{50}\right)$ in the surface soils occupied $11.13 \%-44.36 \%$ of the total particles, with a mean value of $24.74 \%$. In the transported materials, the proportion of $\mathrm{PM}_{50}$ varied between $0.88 \%$ and $33.96 \%$, with a mean value of $12.28 \%$. Some nutrients were correlated with the particle size composition of the surface sediments (Tables 2 and 3). For instance, there were significant positive correlations between the fine particles $(<50 \mu \mathrm{m}$ in diameter) and SOM, total $\mathrm{N}$, total $\mathrm{P}$ and $\mathrm{K}_{\text {avail. }}$. The Pearson correlation coefficients of these nutrient components with $\mathrm{PM}_{50}$ were $0.506,0.560,0.895$ and 0.742 , respectively, which suggested that most of these nutrients existed in the fine fractions.

\subsection{Nutrient loss with the transported materials}

During aeolian processes, particles in the $50-500 \mu \mathrm{m}$ fraction lead to the heterogeneity of topsoil nutrients and contribute to 'islands of fertility'. Larger particles also induce succession and changes in community organization in grasslands (Ravi et al., 2010; Alvarez et al., 2012) and increase the likelihood of dust production (Munson et al., 2011). However, most of the particles with the diameter $<50 \mu \mathrm{m}$ were transported by suspension and deposited at greater distances from the source region, resulting in important effects on marine and terrestrial ecosystems (Chadwick et al., 1999; Jickells et al., 2005; Duncan et al., 2008; Neff et al., 2008; Field et al., 2012). In the present study 
Table 1 Nutrient content of the surface soils for each sample, along with the standard deviation (SD), mean and coefficient of variation (CV) for each nutrient component

\begin{tabular}{|c|c|c|c|c|c|c|c|c|}
\hline \multirow{2}{*}{\multicolumn{2}{|c|}{ Site/Sample code }} & SOM & Total N & Total P & Total K & $\mathrm{N}_{\text {avail }}$ & $P_{\text {avail }}$ & $\mathrm{K}_{\text {avail }}$ \\
\hline & & \multicolumn{4}{|c|}{$(\mathrm{g} / \mathrm{kg})$} & \multicolumn{3}{|c|}{$(\mathrm{mg} / \mathrm{kg})$} \\
\hline \multirow[t]{5}{*}{ Site 1} & YC01 & 6.58 & 0.40 & 0.66 & 11.00 & 23.90 & 13.17 & 200.00 \\
\hline & YC02 & 12.18 & 0.84 & 0.84 & 11.00 & 60.40 & 23.14 & 250.00 \\
\hline & YC03 & 13.30 & 0.75 & 0.87 & 11.00 & 54.00 & 25.55 & 250.00 \\
\hline & YC04 & 8.68 & 0.65 & 0.85 & 11.00 & 48.40 & 12.72 & 230.00 \\
\hline & YC05 & 10.63 & 0.59 & 0.78 & 11.00 & 46.00 & 14.09 & 220.00 \\
\hline \multirow[t]{5}{*}{ Site 2} & YC06 & 7.04 & 0.53 & 0.74 & 11.00 & 33.70 & 18.67 & 170.00 \\
\hline & YC07 & 8.67 & 0.66 & 0.93 & 11.00 & 54.90 & 24.52 & 200.00 \\
\hline & YC08 & 9.43 & 0.56 & 0.90 & 11.00 & 39.90 & 13.75 & 190.00 \\
\hline & YC09 & 9.04 & 0.57 & 0.85 & 11.00 & 40.00 & 12.60 & 160.00 \\
\hline & YC10 & 9.74 & 0.70 & 0.87 & 11.00 & 62.80 & 12.14 & 170.00 \\
\hline \multirow[t]{5}{*}{ Site 3} & YC11 & 9.57 & 0.72 & 0.97 & 11.00 & 24.80 & 21.31 & 260.00 \\
\hline & YC12 & 14.42 & 1.01 & 1.14 & 11.00 & 70.90 & 24.40 & 240.00 \\
\hline & YC13 & 10.60 & 0.66 & 0.94 & 11.00 & 40.00 & 16.38 & 280.00 \\
\hline & YC14 & 8.46 & 0.49 & 1.00 & 11.00 & 36.50 & 15.92 & 270.00 \\
\hline & YC15 & 7.92 & 0.62 & 1.00 & 11.00 & 24.70 & 16.50 & 300.00 \\
\hline \multirow[t]{5}{*}{ Site 4} & YC16 & 6.28 & 0.54 & 0.69 & 11.00 & 18.50 & 8.71 & 160.00 \\
\hline & YC17 & 6.45 & 0.48 & 0.58 & 11.00 & 26.90 & 13.75 & 170.00 \\
\hline & YC18 & 5.24 & 0.44 & 0.66 & 11.00 & 41.70 & 13.75 & 170.00 \\
\hline & YC19 & 6.39 & 0.37 & 0.65 & 11.00 & 23.90 & 9.39 & 170.00 \\
\hline & YC20 & 5.43 & 0.34 & 0.59 & 11.00 & 27.80 & 8.59 & 130.00 \\
\hline \multicolumn{2}{|c|}{ SD } & 2.54 & 0.16 & 0.15 & 0.00 & 14.94 & 5.32 & 47.96 \\
\hline \multicolumn{2}{|c|}{ Mean } & 8.80 & 0.60 & 0.82 & 11.00 & 39.98 & 15.95 & 209.50 \\
\hline \multicolumn{2}{|c|}{$\mathrm{CV}$} & 0.29 & 0.27 & 0.19 & 0.00 & 0.37 & 0.33 & 0.23 \\
\hline
\end{tabular}

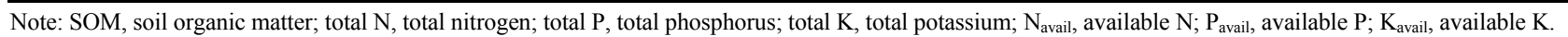

Table 2 Pearson correlation coefficients between the particle size fractions and nutrient components of all surface samples

\begin{tabular}{|c|c|c|c|c|c|c|}
\hline Particle size & SOM & Total P & Total $\mathrm{N}$ & $\mathrm{N}_{\text {avail }}$ & $\mathrm{P}_{\text {avail }}$ & $\mathrm{K}_{\text {avail }}$ \\
\hline$<2 \mu \mathrm{m}$ & 0.402 & $0.846^{* *}$ & $0.521^{*}$ & 0.195 & 0.405 & $0.597^{* *}$ \\
\hline$<5 \mu \mathrm{m}$ & 0.399 & $0.833^{* *}$ & $0.516^{*}$ & 0.140 & 0.393 & $0.629^{* *}$ \\
\hline$<10 \mu \mathrm{m}$ & 0.374 & $0.808^{* *}$ & $0.490^{*}$ & 0.083 & 0.353 & $0.614^{* *}$ \\
\hline$<15 \mu \mathrm{m}$ & 0.342 & $0.782^{* *}$ & $0.455^{*}$ & 0.048 & 0.328 & $0.592^{* *}$ \\
\hline$<20 \mu \mathrm{m}$ & 0.355 & $0.787^{* *}$ & $0.454^{*}$ & 0.050 & 0.337 & $0.620^{* *}$ \\
\hline$<50 \mu \mathrm{m}$ & $0.506^{*}$ & $0.895^{* *}$ & $0.560^{*}$ & 0.197 & 0.442 & $0.742^{* *}$ \\
\hline$<100 \mu \mathrm{m}$ & 0.293 & $0.814^{* *}$ & 0.403 & 0.107 & 0.359 & $0.509^{*}$ \\
\hline$<150 \mu \mathrm{m}$ & 0.016 & $0.582^{* *}$ & 0.141 & -0.099 & 0.222 & 0.294 \\
\hline$<200 \mu \mathrm{m}$ & -0.152 & 0.396 & -0.043 & -0.257 & 0.135 & 0.198 \\
\hline$<250 \mu \mathrm{m}$ & -0.239 & 0.275 & -0.149 & -0.352 & 0.085 & 0.159 \\
\hline$>250 \mu \mathrm{m}$ & 0.239 & -0.275 & 0.149 & 0.352 & -0.085 & -0.159 \\
\hline Median & -0.100 & $-0.641^{* *}$ & -0.184 & 0.051 & -0.161 & -0.326 \\
\hline Mean & 0.171 & -0.340 & 0.081 & 0.322 & -0.140 & -0.258 \\
\hline
\end{tabular}

Note: ${ }^{*}$ and ${ }^{* *}$ mean significance at the 0.05 level and 0.01 level (2-tailed), respectively.

Table 3 Linear regression equations between the particle size fractions $(x)$ and nutrient components $(y)$ of the surface soils

\begin{tabular}{|c|c|c|c|c|}
\hline Particle size & SOM & Total $\mathrm{N}$ & Total P & $\mathrm{K}_{\text {avail }}$ \\
\hline$<2 \mu \mathrm{m}$ & / & $y=0.1054 x+0.3811\left(R^{2}=0.27\right)$ & $y=0.1604 x+0.4960\left(R^{2}=0.72\right)$ & $y=35.4820 x+136.7500\left(R^{2}=0.36\right)$ \\
\hline$<5 \mu \mathrm{m}$ & / & $y=0.0481 x+0.3895\left(R^{2}=0.27\right)$ & $y=0.0728 x+0.5106\left(R^{2}=0.69\right)$ & $y=17.2180 x+135.1000\left(R^{2}=0.40\right)$ \\
\hline$<10 \mu \mathrm{m}$ & / & $y=0.0272 x+0.3993\left(R^{2}=0.24\right)$ & $y=0.0421 x+0.5190\left(R^{2}=0.65\right)$ & $y=10.0080 x+136.7000\left(R^{2}=0.38\right)$ \\
\hline$<15 \mu \mathrm{m}$ & / & $y=0.0196 x+0.4126\left(R^{2}=0.21\right)$ & $y=0.0315 x+0.5274\left(R^{2}=0.61\right)$ & $y=7.4753 x+138.9400\left(R^{2}=0.35\right)$ \\
\hline$<20 \mu \mathrm{m}$ & / & $y=0.0160 x+0.4156\left(R^{2}=0.21\right)$ & $y=0.0260 x+0.5301\left(R^{2}=0.62\right)$ & $y=6.4357 x+136.6300\left(R^{2}=0.39\right)$ \\
\hline$<50 \mu \mathrm{m}$ & $y=0.1310 x+5.5633\left(R^{2}=0.26\right)$ & $y=0.0093 x+0.3665\left(R^{2}=0.31\right)$ & $y=0.0140 x+0.4798\left(R^{2}=0.80\right)$ & $y=3.6280 x+119.7400\left(R^{2}=0.55\right)$ \\
\hline
\end{tabular}

Note: / means no significant correlation between the particle size fractions and SOM at the 0.05 level (2-tailed). 
region, the proportion of $\mathrm{PM}_{50}$ in all transported materials was approximately $12.28 \%$, which contained abundant nutrients. For instance, at the wind velocity of $22 \mathrm{~m} / \mathrm{s}$, the concentrations of SOM, total N, total P and $\mathrm{K}_{\text {avail }}$ of the $\mathrm{PM}_{50}$ fraction were $18.70 \mathrm{~g} / \mathrm{kg}, 1.30$ $\mathrm{g} / \mathrm{kg}, 1.90 \mathrm{~g} / \mathrm{kg}$ and $482.50 \mathrm{mg} / \mathrm{kg}$, respectively (Table 4). In the absence of human disturbance, the loss of SOM, total $\mathrm{N}$, total $\mathrm{P}$ and $\mathrm{K}_{\text {avail }}$ from the surface soils of the study region averaged 5.70, 0.50, 0.40 and 0.12 $\mathrm{mg} / \mathrm{m}^{2}$, respectively for the combined $\mathrm{PM}_{50}$ emission rates (Table 5). Therefore, our results further verified aeolian processes play an important role in nutrient loss and have a substantial impact on sandy desertification in arid and semi-arid regions (Okin et al., 2004; Soderberg and Compton, 2007; Farsang et al., 2012). At the wind velocities of $14-22 \mathrm{~m} / \mathrm{s}$ in the wind tunnel, the coefficients of variation (CVs) for SOM, total P, total $\mathrm{N}$ and $\mathrm{K}_{\text {avail }}$ in the transported materials were usually $<5 \%$, which suggested that after the erodible fine particles were transported away from the soil surfaces at low wind velocities, the following relatively high wind velocities may not result in significant change in nutrient loss.

Table 4 Results from the regressions (using the equations listed in Table 3) of nutrient content of the fine particle fractions in the transported soil materials at the wind velocity of $22 \mathrm{~m} / \mathrm{s}$

\begin{tabular}{ccccc}
\hline $\begin{array}{c}\text { Particle } \\
\text { size }\end{array}$ & $\begin{array}{c}\text { SOM } \\
(\mathrm{g} / \mathrm{kg})\end{array}$ & $\begin{array}{c}\text { Total N } \\
(\mathrm{g} / \mathrm{kg})\end{array}$ & $\begin{array}{c}\text { Total P } \\
(\mathrm{g} / \mathrm{kg})\end{array}$ & $\begin{array}{c}\mathrm{K}_{\text {avail }} \\
(\mathrm{mg} / \mathrm{kg})\end{array}$ \\
\hline$<2 \mu \mathrm{m}$ & N/A & 10.90 & 16.50 & $3,685.00$ \\
$<5 \mu \mathrm{m}$ & N/A & 5.20 & 7.80 & $1,856.90$ \\
$<10 \mu \mathrm{m}$ & $\mathrm{N} / \mathrm{A}$ & 3.10 & 4.70 & $1,137.50$ \\
$<15 \mu \mathrm{m}$ & N/A & 2.40 & 3.70 & 886.50 \\
$<20 \mu \mathrm{m}$ & $\mathrm{N} / \mathrm{A}$ & 2.00 & 3.10 & 780.20 \\
$<50 \mu \mathrm{m}$ & 18.70 & 1.30 & 1.90 & 482.50 \\
\hline
\end{tabular}

Note: N/A means data were not included because of weak correlations between the particle size fractions and SOM.

Table 5 Nutrient content of $\mathrm{PM}_{50}$ (particle size $<50 \mu \mathrm{m}$ in diameter) in the transported soil materials and the mean nutrient content of the surface soils for each sample at the wind velocity of $22 \mathrm{~m} / \mathrm{s}$ for intact (A), half-crushed (B) and completely crushed (C) treatments

\begin{tabular}{|c|c|c|c|c|c|c|c|c|c|c|c|c|c|c|c|c|}
\hline \multirow{2}{*}{\multicolumn{2}{|c|}{ Site/Sample code }} & \multicolumn{3}{|c|}{$\begin{array}{l}\text { Nutrient content of } \mathrm{PM}_{50} \\
\left(\mathrm{~g} / \mathrm{m}^{2}\right)\end{array}$} & \multicolumn{3}{|c|}{$\begin{array}{c}\mathrm{SOM} \\
\left(\mathrm{mg} / \mathrm{m}^{2}\right)\end{array}$} & \multicolumn{3}{|c|}{$\begin{array}{l}\text { Total P } \\
\left(\mathrm{mg} / \mathrm{m}^{2}\right)\end{array}$} & \multicolumn{3}{|c|}{$\begin{array}{l}\text { Total N } \\
\left(\mathrm{mg} / \mathrm{m}^{2}\right)\end{array}$} & \multicolumn{3}{|c|}{$\begin{array}{c}\mathrm{K}_{\text {avail }} \\
\left(\mathrm{mg} / \mathrm{m}^{2}\right)\end{array}$} \\
\hline & & A & B & $\mathrm{C}$ & A & B & $\mathrm{C}$ & A & B & $\mathrm{C}$ & A & B & $\mathrm{C}$ & A & B & $\mathrm{C}$ \\
\hline \multirow[t]{5}{*}{ Site 1} & YC01 & 0.02 & I & 0.13 & 5.60 & I & 5.60 & 0.50 & I & 0.50 & 0.40 & 1 & 0.40 & 0.12 & I & 0.12 \\
\hline & YC02 & 0.46 & 0.01 & 19.32 & 5.60 & 5.60 & 8.10 & 0.50 & 0.50 & 0.80 & 0.40 & 0.40 & 0.50 & 0.12 & 0.12 & 0.19 \\
\hline & YC03 & 0.69 & 0.46 & 20.65 & 5.70 & 5.60 & 8.30 & 0.50 & 0.50 & 0.80 & 0.40 & 0.40 & 0.60 & 0.12 & 0.12 & 0.19 \\
\hline & YC04 & 0.84 & 0.16 & 21.12 & 5.70 & 5.60 & 8.30 & 0.50 & 0.50 & 0.80 & 0.40 & 0.40 & 0.60 & 0.12 & 0.12 & 0.2 \\
\hline & YC05 & 0.56 & 0.20 & 11.19 & 5.60 & 5.60 & 7.00 & 0.50 & 0.50 & 0.60 & 0.40 & 0.40 & 0.50 & 0.12 & 0.12 & 0.16 \\
\hline \multirow[t]{5}{*}{ Site 2} & YC06 & 0.54 & 0.19 & 18.10 & 5.60 & 5.60 & 7.90 & 0.50 & 0.50 & 0.70 & 0.40 & 0.40 & 0.50 & 0.12 & 0.12 & 0.19 \\
\hline & YC07 & 0.93 & 1.64 & 18.08 & 5.70 & 5.80 & 7.90 & 0.50 & 0.50 & 0.70 & 0.40 & 0.40 & 0.50 & 0.12 & 0.13 & 0.19 \\
\hline & YC08 & 1.14 & 0.25 & 14.11 & 5.70 & 5.60 & 7.40 & 0.50 & 0.50 & 0.70 & 0.40 & 0.40 & 0.50 & 0.12 & 0.12 & 0.17 \\
\hline & YC09 & 0.71 & 0.19 & 12.94 & 5.70 & 5.60 & 7.30 & 0.50 & 0.50 & 0.70 & 0.40 & 0.40 & 0.50 & 0.12 & 0.12 & 0.17 \\
\hline & YC10 & 0.36 & 0.20 & 9.48 & 5.60 & 5.60 & 6.80 & 0.50 & 0.50 & 0.60 & 0.40 & 0.40 & 0.50 & 0.12 & 0.12 & 0.15 \\
\hline \multirow[t]{5}{*}{ Site 3} & YC11 & 1.46 & 0.59 & 29.28 & 5.80 & 5.60 & 9.40 & 0.50 & 0.50 & 0.90 & 0.40 & 0.40 & 0.60 & 0.13 & 0.12 & 0.23 \\
\hline & $\mathrm{YC} 12$ & 1.59 & 0.61 & 71.21 & 5.80 & 5.60 & 14.90 & 0.50 & 0.50 & 1.50 & 0.40 & 0.40 & 1.00 & 0.13 & 0.12 & 0.38 \\
\hline & YC13 & 1.30 & 0.59 & 26.54 & 5.70 & 5.60 & 9.00 & 0.50 & 0.50 & 0.90 & 0.40 & 0.40 & 0.60 & 0.12 & 0.12 & 0.22 \\
\hline & YC14 & 6.42 & 0.60 & 30.01 & 6.40 & 5.60 & 9.50 & 0.60 & 0.50 & 0.90 & 0.40 & 0.40 & 0.60 & 0.14 & 0.12 & 0.23 \\
\hline & YC15 & 1.05 & 1.20 & 16.10 & 5.70 & 5.70 & 7.70 & 0.50 & 0.50 & 0.70 & 0.40 & 0.40 & 0.50 & 0.12 & 0.12 & 0.18 \\
\hline \multirow[t]{5}{*}{ Site 4} & YC16 & 0.78 & 1.05 & 7.42 & 5.70 & 5.70 & 6.50 & 0.50 & 0.50 & 0.60 & 0.40 & 0.40 & 0.40 & 0.12 & 0.12 & 0.15 \\
\hline & YC17 & 0.14 & 0.09 & 5.44 & 5.60 & 5.60 & 6.30 & 0.50 & 0.50 & 0.60 & 0.40 & 0.40 & 0.40 & 0.12 & 0.12 & 0.14 \\
\hline & YC18 & 0.42 & 0.94 & 1.99 & 5.60 & 5.70 & 5.80 & 0.50 & 0.50 & 0.50 & 0.40 & 0.40 & 0.40 & 0.12 & 0.12 & 0.13 \\
\hline & YC19 & 0.63 & 0.79 & 6.00 & 5.60 & 5.70 & 6.30 & 0.50 & 0.50 & 0.60 & 0.40 & 0.40 & 0.40 & 0.12 & 0.12 & 0.14 \\
\hline & YC20 & 0.50 & 0.37 & 6.57 & 5.60 & 5.60 & 6.40 & 0.50 & 0.50 & 0.60 & 0.40 & 0.40 & 0.40 & 0.12 & 0.12 & 0.14 \\
\hline \multicolumn{2}{|c|}{ Mean } & 1.03 & 0.53 & 17.28 & 5.70 & 5.60 & 7.80 & 0.50 & 0.50 & 0.70 & 0.40 & 0.40 & 0.50 & 0.12 & 0.12 & 0.18 \\
\hline
\end{tabular}

Note: / means data were unavailable. 


\section{Conclusions}

Aeolian processes caused nutrient loss through the export of fine particles $(<50 \mu \mathrm{m}$ in diameter), highlighting the importance of these processes for sandy desertification in the Mu Us Desert. Our experiments showed that the fine particles $(12.28 \%$ of all transported materials) carrying substantial nutrient loadings were exported during aeolian processes at the sampling sites. Under high-intensity aeolian processes, after the erodible fine particles were transported away from the soil surfaces at low wind velocity (i.e. 14 $\mathrm{m} / \mathrm{s}$ ), the following relatively high wind velocity (i.e. $22 \mathrm{~m} / \mathrm{s}$ ) may have no significant effect on nutrient transport as the CVs for the losses of SOM, total P, total $\mathrm{N}$ and $\mathrm{K}_{\text {avail }}$ were usually $<5 \%$. Our experiments confirmed that in addition to the important role of 'islands of fertility' in sandy desertification, aeolian processes causing nutrient loss through the export of fine particles also play a key role in sandy desertification in this region.

\section{Acknowledgments}

This study was supported by the National Natural Science Foundation of China (41225001). We thank Professor ZHAO Aiguo from Key Laboratory of Desert and Desertification, Cold and Arid Regions Environmental and Engineering Research Institute, Chinese Academy of Sciences for his advice on construction of the aeolian sand trap, and Mr. LI Hong for his operation of the wind tunnel. Special thanks are given to anonymous referees for their critical comments on this manuscript.

\section{References}

Alvarez L J, Epstein H E, Li J, et al. 2012. Aeolian process effects on vegetation communities in an arid grassland ecosystem. Ecology and Evolution, 2(4): 809-821.

Bosatta E, Ågren G. 1997. Theoretical analyses of soil texture effects on organic matter dynamics. Soil Biology \& Biochemistry, 29(11-12): 1633-1638.

Chadwick O A, Derry L A, Vitousek P M, et al. 1999. Changing sources of nutrients during four million years of ecosystem development. Nature, 397: 491-497.

Dexter A R. 2004. Soil physical quality Part I. Theory, effects of soil texture, density, and organic matter, and effects on root growth. Geoderma, 120: 201-214.

Dong Y X, Liu Y Z, Liu Y H. 1995. Study on Some Problems of Sandy Desertification. Xi'an: Xi'an Cartographic Press, 1-250. (in Chinese)

Dong Z, Wang H, Liu X, et al. 2004. The blown sand flux over a sandy surface: a wind tunnel investigation on the fetch effect. Geomorphology, 57: 117-127.

Duncan D H, Dorrough J, White M, et al. 2008. Blowing in the wind? Nutrient enrichment of remnant woodlands in an agricultural landscape. Landscape Ecology, 23: 107-119.

Farsang A H, Bartus M, Négyesi G, et al. 2012. Estimation of nutrient movement caused by wind erosion on chernozems based on wind channel experiments. Geophysical Research Abstracts, 14: 13798.

Field J P, Breshears D D, Whicker J J, et al. 2012. Sediment capture by vegetation patches: Implications for desertification and increased resource redistribution. Journal of Geophysical Research, 117, G01033, doi: 10.1029/2011JG001663.

Garner W, Steinberger Y. 1989. A proposed mechanism for the formation of 'Fertile Islands' in the desert ecosystem. Journal of Arid Environments, 16: 257-262.

Hobbs R J, Harris J A. 2001. Restoration ecology: Repairing the earth's ecosystems in the new millennium. Restoration Ecology, 9(2): 239-246.

Hoffmann C, Funk R, Reiche M, et al. 2011. Assessment of extreme wind erosion and its impacts in Inner Mongolia, China. Aeolian Research, 3: 343-351.

Huang F X, Niu H S, Wang M X, et al. 2001. The relationship between vegetation cover and sand transport flux at $\mathrm{Mu}$ Us Sandyland. Acta Geographica Sinica, 56(6): 700-710. (in Chinese)

Jickells T D, An Z S, Andersen K K, et al. 2005. Global iron connections between desert dust, ocean biogeochemistry, and climate. Science, 308: 67-71.

Larney F J, Bullock M S, Janzen H H, et al. 1998. Wind erosion effects on nutrient redistribution and soil productivity. Journal of Soil and Water Conservation, 53: 133-140.

Leys J, McTainsh G. 1994. Soil loss and nutrient decline by wind erosion-cause for concern. Australian Journal of Soil and Water Conservation, 7: 30-35.

Li F R, Kang L F, Zhang H, et al. 2005. Changes in intensity of wind erosion at different stages of degradation development in grasslands of Inner Mongolia, China. Journal of Arid Environments, 62: $567-585$.

Li J, Okin G S, Alvarez L, et al. 2007. Quantitative effects of vegetation cover on wind erosion and soil nutrient loss in a desert grassland of southern New Mexico, USA. Biogeochemistry, 85: 317-332.

Li J, Okin G S, Alvarez L, et al. 2008. Effects of wind erosion on the spatial heterogeneity of soil nutrients in two desert grassland communities. Biogeochemistry, 88: 73-88.

Li S, Yang P, Dong Y X, et al. 2010. Land Sandy Desertification and Its Control in Xizang. Beijing: Science Press, 1-501. (in Chinese)

Middleton N, Thomas D. 1992. World Atlas of Desertification: United Nations Environmental Programme. London: Edward Arnold, $15-45$.

Munson S M, Belnap J, Okin G S. 2011. Responses of wind erosion to climate-induced vegetation changes on the Colorado Plateau. Proceedings of the National Academy of Sciences of the United States of America, 108(10): 3854-3859.

Neff J C, Ballantyne A P, Farmer G L, et al. 2008. Increasing eolian dust deposition in the western United States linked to human activity. 
Nature Geoscience, 1: 189-195.

Nelson D W, Sommers L E. 1982. Total carbon, organic carbon and organic matter. In: Page A L, Miller R H, Keeney D R. Methods of Soil Analysis. Part 2. Chemical and Microbiological Properties. Madison: Soil Science Society of America Inc., 539-579.

Okin G S, Gillette D A. 2001. Distribution of vegetation in wind-dominated landscapes: Implications for wind erosion modeling and landscape processes. Journal of Geophysical Research, 106(D9): 9673-9683.

Okin G S, Mahowald N, Chadwick O A, et al. 2004. Impact of desert dust on the biogeochemistry of phosphorus in terrestrial ecosystems. Global Biogeochemical Cycles, 18, GB2005, doi: 10.1029/2003GB002145.

Okin G S, Li J, Alvarez L, et al. 2008. Feedbacks between aeolian processes, vegetation productivity, and nutrient flux in deserts. In: Joint Meeting of The Geological Society of America, Soil Science Society of America, American Society of Agronomy, Crop Science Society of America, Gulf Coast Association of Geological Societies with the Gulf Coast Section of SEPM. Texas: George R. Brown Convention Center, 51-52.

Okin G S, Parsons A J, Wainwright J, et al. 2009. Do changes in connectivity explain desertification? BioScience, 59: 237-244.

Ravi S, D’Odorico P, Wang L, et al. 2009. Post-fire resource redistribution in desert grasslands: a possible negative feedback on land degradation. Ecosystems, 12: 434-444.

Ravi S, D'Odorico P, Huxman T, et al. 2010. Interactions between soil erosion processes and fires: implications for the dynamics of fertility islands. Rangeland Ecology \& Management, 63: 267-274.

Reynolds R, Belnap J, Reheis M, et al. 2001. Aeolian dust in Colorado Plateau soils: Nutrient inputs and recent change in source. Proceedings of the National Academy of Sciences of the United States of America, 98(13): 7123-7127.

Schlesinger W H, Reynolds J F, Cunningham G L, et al. 1990. Biological feedbacks in global desertification. Science, 247: 1043-1048.

Schlesinger W H, Pilmanis A M. 1998. Plant-soil interactions in deserts. Biogeochemistry, 42: 169-187.

Shao Y. 2008. Physics and Modeling of Wind Erosion. Berlin: Springer, $1-456$.

Shao Y, Wyrwoll K H, Chappell A, et al. 2011. Dust cycle: An emerging core theme in Earth system science. Aeolian Research, 2: 181-204.
Soderberg K, Compton J S. 2007. Dust as a nutrient source for fynbos ecosystems, South Africa. Ecosystems, 10: 550-561.

Wang X, Chen F, Dong Z, et al. 2005a. Evolution of the southern Mu Us Desert in north China over the past 50 years: an analysis using proxies of human activity and climate parameters. Land Degradation \& Development, 16: 351-366.

Wang X, Dong Z, Yan P, et al. 2005b. Wind energy environments and dunefield activity in the Chinese deserts. Geomorphology, 65: 33-48.

Wang X, Chen F, Dong Z. 2006. The relative role of climatic and human factors in desertification in semiarid China. Global Environmental Change, 16: 48-57.

Wang X, Hasi E, Zhou Z, et al. 2007. Significance of variations in the wind energy environment over the past 50 years with respect to dune activity and desertification in arid and semiarid northern China. Geomorphology, 86: 252-266.

Wang X, Chen F, Hasi E, et al. 2008a. Desertification in China: An assessment. Earth-Science Reviews, 88: 188-206.

Wang X, Xia D, Wang T, et al. 2008b. Dust sources in arid and semi-arid China and southern Mongolia: impacts of geomorphologic setting and surface materials. Geomorphology, 97: 583-600.

Wang X, Lang L, Hua T, et al. 2012a. Characteristics of the Gobi desert and their significance for dust emissions in the Ala Shan Plateau (Central Asia): An experimental study. Journal of Arid Environments, 81: 35-46.

Wang X, Lang L, Zhang C, et al. 2012b. The influence of near-surface winds on Sr isotope composition of aeolian sediments: a wind tunnel experiment. Chemical Geology, 308-309: 10-17.

Wang X. 2013a. Sandy desertification: Borne on the wind. Chinese Science Bulletin, 58: 2395-2403.

Wang X, Wang G, Lang L, et al. 2013b. Aeolian transport and sandy desertification in semiarid China: a wind tunnel approach. Land Degradation \& Development, 24: 605-612.

Zhang X Y, Gong S L, Zhao T L, et al. 2003. Sources of Asian dust and role of climate change versus desertification in Asian dust emission. Geophysical Research Letters, 30(24): 2272.

Zobeck T M, Fryrear D W, Pettit R D. 1989. Management effects on wind-eroded sediment and plant nutrients. Journal of Soil and Water Conservation, 44: 160-163. 